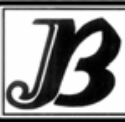

J. bio-sci. 18: 1-8, 2010

ISSN 1023-8654

http://www.banglajol.info/index.php/JBS/index

\title{
ASSESSMENT OF GENETIC VARIABILITY, CORRELATION AND PATH ASSOCIATION IN RICE (ORYZA SATIVA L.)
}

\author{
S K Yadav*, B G Suresh, Praveen Pandey, Binod Kumar \\ Department of Genetics and Plant Breeding, Allahabad Agricultural Institute-Deemed University, \\ Allahabad-211007 (UP) India
}

\begin{abstract}
Context: Direct selection based on crop yields is often a paradox in breeding programmes because yield is a complex polygenically inherited character, influenced by its component traits.

Objectives: The present research work was taken up to assess genetic variability, phenotypic and genotypic associations between various components of grain yield to provide basis for selection and yield improvement in rice.

Materials and Methods: Correlation coefficient and path association are used to find out the degree (strength) and direction of relationship between two or more variable and for fixing up the characters which are having decisive role in influencing the yield. Therefore, a field experiment was carried out to establish the extent of association between yield and yield components and others characters in rice. Analysis of variance revealed that significant amount of genetic variability was present in the entire characters studied.
\end{abstract}

Results: High heritability coupled with high to moderate genetic advance as $\%$ of mean was observed on plant height seed yield per plant, biological yield, harvest index, test weight and number of spikelets per panicle suggesting preponderance of additive gene action in the expression of these characters. The correlation coefficient between seed yield per plant and other quantitative attributing to yield showed that grain yield was significantly and positively associated with harvest index, number of tillers per hill, number of panicle per plant, panicle length, number of spikelet's per panicle and test weight at both genotypic and phenotypic levels. Path coefficient at genotypic level revealed that harvest index biological yield, number of tillers per hill, panicle length, number of spikelets per panicle, plant height and test weight had direct positive effect on seed yield per hill, indicating these are the main contributors to yield.

Conclusion: From the correlation and path study it may be concluded that harvest index, number of tillers per hill, panicle length, and number of spikelet per panicle and test weight are the most important characters that contributed directly to seed yield per hill. Thus a genotype with higher magnitude of these traits could be either selected from existing genotypes or evolved by breeding program for genetic improvement of yield in rice.

Key words: Rice, variability, heritability, agro-morphological traits, correlation and path

\section{Introduction}

Rice is the most important cereal food crop of India. It occupies about $23.3 \%$ of gross cropped area and contributes $43 \%$ of total food grain production and $46 \%$ of the total cereal production of the country. Among the rice growing countries in the world, India has the largest area under rice crop and ranks second in production next to China. Knowledge on the genetic architecture of genotypes is necessary to formulate efficient breeding methodology. The systematic breeding programme involves the steps like creating genetic variability practicing selection and utilization of selected genotypes to evolve promising varieties. Direct selection based on crop yields is often a paradox in breeding programmes because yield is a complex polygenically inherited character, influenced by its component traits.

Correlation coefficient analysis measures the mutual relationship between various plant characters and determines the component characters on which selection can be based for genetic improvement in yield. While selecting the suitable plant type, correlation studies would provide reliable information in nature, extent

* Corresponding author E-mail: gentic.ksuni@yahoo.com 
and the direction of the selection, especially when the breeder needs to combine high yield potentials with desirable agronomic traits and grain quality characters. A positive value of correlation shows that the changes of two variables are in the same direction, i.e., high value of one variable are associated with high values of other and vice-versa. When correlation is negative the movements are in opposite directions, i.e., high values of one variable are associated with low values of other. The breeder is always concerned for the selection of superior genotypes on the basis of phenotypic expression. However for the quantitative characters, genotypes are influenced by environment, thereby affecting the phenotypic expression. Information regarding the nature and extent of association of morphological characters would be helpful in developing suitable plant type, in addition to the improvement of yield a complex character for which, direct selection is not effective.

The better way of exploiting genetic correlation and path coefficient with several traits having high heritability is to construct a selection index that combines information on all the characters associated with the dependent variable. Efforts are to be taken with a systematic research approach to exploit the yield potential by direct and indirect selection. The use of correlation coefficient and path analysis is to establish the extent of association between yield and yield components and others characters and for fixing up the characters which are having decisive role in influencing the yield. Wide difference between genotypic and phenotypic correlations between two characters is due to dual nature of phenotypic correlation, which is determined by genotypic and environmental correlations and heritability of the characters (Falconer 1981). The nature and extent of genetic variation governing the inheritance of characters and association will facilitate effective genetic improvement. Keeping in view the above perspectives, the present research work was taken up to assessing genetic variability, phenotypic and genotypic associations between various components of grain yield to provide basis for selection and yield improvement in rice.

\section{Materials and Methods}

A field experiment was carried out to study the extent of genetic variability, correlation and path coefficient in rice for yield and associated traits. Forty rice genotypes from diverse sources were evaluated in a randomized block design with three replications in $2 \mathrm{~m}^{2}$ plot keeping $20 \times 15 \mathrm{~cm}$ spacing at field experimentation centre of Allahabad Agricultural Institute-Deemed University, Allahabad during wet season of 2007 and 2008 two consecutive years. Standard agronomic practices compatible to this ago-ecological zone were adopted to ensure good crop growth. The observations were recorded on 10 randomly selected plants from each replication for various characters viz., days to $50 \%$ flowering, plant height, number of tillers per hill, panicle length, number of panicles per hill, number of spikelets per panicle, flag leaf length, flag leaf width, grain yield per hill, biological yield per hill, harvest index and test weight. The mean performance of individual genotype over two years was pooled and employed for statistical analysis. Analysis of variance to test the significance for each character was carried out as per methodology advocated by Panse and Sukhatme (1967). PCV and GCV were calculated by the formula given by Burton (1952), heritability in broad sense $\left(h^{2}\right)$ by Burton and De Vane (1953), and genetic advance i.e. the expected genetic gain were calculated by using the procedure given by Johnson et al. (1955). Correlation coefficient and path coefficient was worked out as method suggested by Al Jibouri et al. (1958), Deway and Lu (1959) respectively. The estimated values were compared with table values of correlation coefficient to test the significance of correlation coefficient prescribed by Fisher and Yates (1967).

\section{Results}

The mean sums of squares for the characters studied (Table 1) revealed that the mean sum of squares due to genotypes were significant for all the characters. This suggests that the genotypes selected were genetically variable and considerable amount of variability existed among them. The development of an 
effective plant breeding programme depends on the existence of genetic variability. The variability parameters obtained from the pooled data are presented in Table 2. The data revealed that a wide range of genotypic $(\mathrm{Vg})$ and phenotypic variance $(\mathrm{Vp})$ was observed for all the characters. The higher magnitude of genotypic (GCV) and phenotypic coefficients of variation (PCV) was recorded for traits like seed yield per hill, harvest index, biological yield, number of spikelets per panicle, flag leaf length, number of tiller per hill, plant height. However, moderate estimates were observed for panicle length and test weight rest of the character showed low estimates of GCV and PCV. The studies on genotypic and phenotypic coefficient of variation indicated that the presence of high amount of variance and role of the environment on the expression of these traits.

Table 1. Analysis of variance for different quantitative characters in rice genotypes

\begin{tabular}{|c|c|c|c|c|}
\hline \multirow{2}{*}{ SI. No. } & \multirow{2}{*}{ Characters } & \multicolumn{3}{|c|}{ Source of variation } \\
\hline & & Replication (df.=2) & Treatment $(\mathrm{df}=39)$ & Error (df=78) \\
\hline 1 & Days to $50 \%$ flowering & 46.53 & $117.05^{\star \star}$ & 5.25 \\
\hline 2 & Plant height & 3.22 & $463.49 * \star$ & 1.84 \\
\hline 3 & No. of tillers/ hill & 4.72 & $12.19 * *$ & 1.54 \\
\hline 4 & No. of panicles/ hill & 3.76 & $8.86 * *$ & 1.89 \\
\hline 5 & Flag leaf length & 14.12 & $50.44^{\star \star}$ & 1.32 \\
\hline 6 & Flag Leaf Width & 0.007 & $0.009 *$ & 0.004 \\
\hline 7 & Panicle length & 3.74 & $10.40^{* *}$ & 0.39 \\
\hline 8 & No. of spikelets/ panicles & 59.28 & $1034.01^{\star \star}$ & 21 \\
\hline 9 & Biological yield(g) & 2.16 & $240.22^{\star *}$ & 2.37 \\
\hline 10 & Seed yield / hill & 22.03 & $115.32^{\star *}$ & 1.12 \\
\hline 11 & Harvest index & 60.82 & $302.53^{\star *}$ & 4.35 \\
\hline 12 & Test weight & 8.17 & $12.37^{\star \star}$ & 0.23 \\
\hline
\end{tabular}

*Significant at $5 \%$ level and ${ }^{* *}$ significant at $1 \%$ level

Table 2. Genetic variability parameters for different quantitative traits in rice

\begin{tabular}{|c|c|c|c|c|c|c|c|c|}
\hline \multirow{2}{*}{ SI. No. } & \multirow{2}{*}{ Characters } & \multicolumn{2}{|c|}{ Variance } & \multirow{2}{*}{ GCV\% } & \multirow{2}{*}{ PCV\% } & \multirow{2}{*}{$\mathrm{H}(\mathrm{bs}) \%$} & \multirow{2}{*}{ GA } & \multirow{2}{*}{ GG } \\
\hline & & $\mathrm{Vg}$ & $V p$ & & & & & \\
\hline 1 & Days to $50 \%$ flowering & 37.26 & 42.52 & 6.23 & 6.65 & 87.6 & 11.77 & 12.01 \\
\hline 2 & Plant height & 153.88 & 155.73 & 12.89 & 12.96 & 98.8 & 25.40 & 26.39 \\
\hline 3 & No. of tillers/ hill & 3.54 & 5.09 & 12.58 & 15.07 & 69.7 & 3.23 & 21.64 \\
\hline 4 & No. of panicles/ hill & 2.32 & 4.21 & 11.42 & 15.39 & 55.1 & 2.33 & 17.47 \\
\hline 5 & Flag leaf length & 16.37 & 17.70 & 16.17 & 16.81 & 92.5 & 8.01 & 32.04 \\
\hline 6 & Flag Leaf Width & 0.002 & 0.006 & 3.20 & 6.21 & 26.6 & 0.04 & 3.40 \\
\hline 7 & Panicle length & 3.33 & 3.73 & 8.01 & 8.48 & 89.4 & 3.55 & 15.61 \\
\hline 8 & No. of spikelets/panicles & 337.43 & 359.12 & 14.95 & 15.42 & 94.4 & 36.68 & 29.85 \\
\hline 9 & Biological yield(g) & 79.28 & 81.65 & 13.39 & 13.59 & 97.1 & 28.07 & 27.19 \\
\hline 10 & Seed yield / hill & 38.06 & 39.19 & 15.05 & 15.27 & 97.1 & 12.52 & 30.56 \\
\hline 11 & Harvest index & 99.39 & 103.74 & 16.03 & 16.37 & 95.8 & 20.10 & 32.32 \\
\hline 12 & Test weight & 4.04 & 4.28 & 8.89 & 9.14 & 94.6 & 24.03 & 17.81 \\
\hline
\end{tabular}

In the present study high heritability was observed for traits like; plant height (98.8\%), biological yield $(97.1 \%)$, seed yield per hill $(97.1 \%)$, harvest index $(95.8 \%)$, test weight $(94.6 \%)$, number of spikelets per panicle (94.4\%), flag leaf length (92.5\%). Panicle length (89.4\%), days to $50 \%$ flowering $(87.6 \%)$, whereas, characters like; number of tillers per hill (69.7\%), number of panicles per hill (55.1\%) depicted moderate estimate of heritability. Remaining characters showed low estimates of heritability (Table 2).

The estimates of correlation coefficients (Table 3) revealed that, in general, the genotypic and the phenotypic correlation coefficients showed similar trend but genotypic correlation coefficients were of higher in magnitude than the corresponding phenotypic correlation coefficients. The correlation coefficient between 
seed yield per plant and other quantitative attributing to yield showed that seed yield was significantly and positively associated with number of tillers per hill $(0.356,0.311)$, number of panicle per plant $(0.465,0.366)$, panicle length $(0.305,0.283)$, number of spikelet's per panicle $(0.320,0.301)$, test weight $(0.207,0.197)$ and harvest index $(0.625,0.626)$ at both genotypic and phenotypic levels.

Table 3. Estimates of genotypic (upper) and phenotypic (lower) correlation coefficients among different quantitative characters in rice

\begin{tabular}{|c|c|c|c|c|c|c|c|c|c|c|c|c|}
\hline S. No & Characters & $\begin{array}{l}\text { Plant } \\
\text { height }\end{array}$ & $\begin{array}{c}\text { No. of } \\
\text { tillers/ } \\
\text { hill }\end{array}$ & $\begin{array}{l}\text { No. of } \\
\text { panicle/ } \\
\text { plant }\end{array}$ & $\begin{array}{l}\text { Flag leaf } \\
\text { length }\end{array}$ & $\begin{array}{l}\text { Flag leaf } \\
\text { width }\end{array}$ & $\begin{array}{l}\text { Panicle } \\
\text { length }\end{array}$ & $\begin{array}{l}\text { No. of } \\
\text { spikelet/ } \\
\text { panicle }\end{array}$ & $\begin{array}{l}\text { Biol. } \\
\text { yield }\end{array}$ & $\begin{array}{l}\text { Harvest } \\
\text { index }\end{array}$ & $\begin{array}{c}\text { Test } \\
\text { weight }\end{array}$ & $\begin{array}{c}\text { Seed } \\
\text { yield/ hill }\end{array}$ \\
\hline \multirow{2}{*}{1} & \multirow{2}{*}{ Days to $50 \%$ flowering } & 0.082 & -0.113 & $-0.214^{*}$ & 0.099 & -0.178 & -0.120 & 0.086 & -0.133 & -0.045 & -0.079 & -0.161 \\
\hline & & 0.077 & -0.098 & -0.146 & 0.093 & -0.128 & -0.107 & 0.076 & -0.133 & -0.032 & -0.059 & -0.142 \\
\hline \multirow{2}{*}{2} & \multirow{2}{*}{ Plant height } & & 0.098 & 0.115 & $0.305^{\star \star}$ & $-0.189^{*}$ & $0.295^{\star \star}$ & 0.156 & -0.063 & 0.174 & -0.013 & -0.114 \\
\hline & & & 0.090 & 0.090 & $0.293^{\star *}$ & -0.105 & $0.275^{\star *}$ & 0.152 & -0.059 & 0.165 & -0.013 & -0.112 \\
\hline \multirow{2}{*}{3} & \multirow{2}{*}{ No. of tillers / hill } & & & $0.985^{\star \star}$ & 0.182 & $0.328^{* *}$ & $-0.218^{*}$ & -0.151 & 0.109 & $0.221^{*}$ & $-0.202^{*}$ & $0.356^{\star \star}$ \\
\hline & & & & $0.873^{\star *}$ & 0.132 & 0.171 & $-0.211^{*}$ & -0.126 & 0.084 & $0.204^{*}$ & -0.166 & $0.311^{\star \star}$ \\
\hline \multirow{2}{*}{4} & \multirow{2}{*}{ No. of panicle/plant } & & & & $0.182^{*}$ & $0.387^{\star \star}$ & $-0.283^{\star \star}$ & -0.140 & $0.232^{*}$ & $0.222^{\star}$ & $-0.228^{*}$ & $0.465^{\star \star}$ \\
\hline & & & & & 0.117 & 0.144 & $-0.222^{*}$ & -0.086 & 0.157 & $0.197^{*}$ & -0.178 & $0.366^{* *}$ \\
\hline \multirow{2}{*}{5} & \multirow{2}{*}{ Flag leaf length } & & & & & 0.171 & 0.143 & $0.223^{*}$ & $-0.197^{*}$ & $0.182^{*}$ & -0.139 & 0.015 \\
\hline & & & & & & 0.088 & 0.139 & $0.216^{*}$ & $-0.185^{\star}$ & 0.166 & -0.135 & 0.012 \\
\hline \multirow{2}{*}{6} & \multirow{2}{*}{ flag leaf width } & & & & & & $-0.608^{* \star}$ & -0.156 & 0.123 & $-0.245^{\star \star}$ & -0.075 & -0.143 \\
\hline & & & & & & & $-0.281^{* *}$ & -0.038 & 0.054 & -0.133 & -0.038 & 0.113 \\
\hline \multirow{2}{*}{7} & \multirow{2}{*}{ Panicle length } & & & & & & & -0.035 & -0.061 & $-0.228^{*}$ & -0.039 & $0.305^{\star \star}$ \\
\hline & & & & & & & & 0.006 & -0.053 & $-0.209^{*}$ & -0.045 & $0.283^{* *}$ \\
\hline \multirow{2}{*}{8} & No. of spikelets / & & & & & & & & -0.065 & $0.339 * \star$ & $-0.223^{\star}$ & $0.319^{\star \star}$ \\
\hline & panicle & & & & & & & & -0.062 & $0.319^{\star *}$ & $-0.217^{*}$ & $0.301^{* *}$ \\
\hline \multirow[t]{2}{*}{9} & \multirow{2}{*}{ Biological yield } & & & & & & & & & $-0.475^{\star \star}$ & 0.065 & $-0.378^{\star \star}$ \\
\hline & & & & & & & & & & $-0.480^{* *}$ & 0.059 & $-0.367^{* *}$ \\
\hline \multirow[t]{2}{*}{10} & \multirow{2}{*}{ Harvest index } & & & & & & & & & & 0.138 & $0.625^{\star \star}$ \\
\hline & & & & & & & & & & & 0.136 & $0.626^{* *}$ \\
\hline \multirow[t]{2}{*}{11} & \multirow[t]{2}{*}{ Test weight } & & & & & & & & & & & $0.207^{*}$ \\
\hline & & & & & & & & & & & & $0.199 *$ \\
\hline
\end{tabular}

${ }^{*}$ Significant at $5 \%$ level and ** significant at $1 \%$ level

Table 4. Direct (diagonal values) and indirect effects of different characters on seed yield/hill at genotypic level

\begin{tabular}{|c|c|c|c|c|c|c|c|c|c|c|c|c|}
\hline Characters & $\begin{array}{c}\text { Days to } \\
50 \% \\
\text { flowering }\end{array}$ & $\begin{array}{l}\text { Plant } \\
\text { height }\end{array}$ & $\begin{array}{l}\text { No. of } \\
\text { tillers / } \\
\text { hill }\end{array}$ & $\begin{array}{c}\text { No. of } \\
\text { panicle/ } \\
\text { plant }\end{array}$ & $\begin{array}{c}\text { Flag } \\
\text { leaf } \\
\text { length }\end{array}$ & $\begin{array}{l}\text { Flag } \\
\text { leaf } \\
\text { width }\end{array}$ & $\begin{array}{l}\text { Panicle } \\
\text { length }\end{array}$ & $\begin{array}{l}\text { No. of } \\
\text { spikelets } \\
\text { Ipanicle }\end{array}$ & $\begin{array}{l}\text { Biol. } \\
\text { yield }\end{array}$ & $\begin{array}{c}\text { Harvest } \\
\text { index }\end{array}$ & $\begin{array}{c}\text { Test } \\
\text { weight }\end{array}$ & $\begin{array}{c}\text { Genotypic } \\
\text { correlation } \\
\text { with seed } \\
\text { yield }\end{array}$ \\
\hline Days to $50 \%$ flowering & 3 & -0.0059 & 0.0081 & 0155 & 0072 & 8 & 087 & 52 & 0.0096 & 033 & 0.0057 & -0.161 \\
\hline Plant height & 0.0012 & 0.0146 & 0.0014 & 0.0017 & 0.0045 & -0.0028 & 0.0043 & 0.0023 & -0.0009 & 0.0025 & -0.0002 & $2-0.114$ \\
\hline ars / hill & -0.0521 & 0.0454 & 0.4628 & 0.4557 & 0.0844 & 0.1520 & -0.1007 & -0.0699 & 0.0503 & 0.1022 & -0.0937 & $70.356^{\star \star}$ \\
\hline No. of panicle/plant & 0.0927 & -0.0500 & -0.4269 & -0.4336 & -0.0788 & -0.1676 & 0.1228 & 0.0608 & -0.1007 & -0.0963 & 0.0988 & $0.465^{\star \star}$ \\
\hline Flag leaf length & 0.0033 & 0.0101 & 0.0060 & 0.0060 & 0.0330 & 0.0057 & 0.0047 & 0.0074 & -0.0065 & 0.0060 & -0.0046 & 0.015 \\
\hline flag le & 0.0135 & 0.0143 & -0.0249 & -0.0293 & -0.0130 & -0.0759 & 0.0461 & 0.0118 & -0.0093 & 0.0186 & 0.0056 & -0.143 \\
\hline Panicle length & 0.0135 & -0.0332 & 0.0245 & 0.0319 & -0.0161 & 0.0684 & 0.1126 & 0.0039 & 0.0068 & 0.0257 & 0.0044 & $0.305^{\star \star}$ \\
\hline No. of spikelet/ panicle & 0.0034 & 0.0061 & -0.0060 & -0.0055 & 0.0088 & -0.0061 & -0.0014 & 0.0394 & -0.0026 & 0.0134 & -0.0088 & $30.319^{\star \star}$ \\
\hline Biolos & -0.1183 & -0.0566 & 0.0971 & 0.2076 & -0.1764 & 0.1097 & -0.0542 & -0.0582 & 0.8943 & -0.4256 & 0.0582 & $-0.378^{\star \star}$ \\
\hline Harv & & 0.1690 & 0.2152 & 0.2164 & 0.1769 & -0.2384 & -0.2223 & & -0.4637 & 0.9744 & 0.1341 & $0.625^{\star \star}$ \\
\hline Test weight & -0.0006 & -0.0001 & -0.0015 & -0.0017 & -0.0011 & -0.0006 & -0.0003 & -0.0017 & 0.0005 & 0.0010 & 0.0076 & $0.207^{*}$ \\
\hline
\end{tabular}

As the correlation coefficient is in sufficient to explain true relationship for an effective manipulation of the character, path coefficient was worked out. Path coefficient at genotypic level (Table 4) revealed that harvest index (0.9744), biological yield (0.8943), number of tillers per hill $(0.4628)$, panicle length $(0.1126)$, number of spikelet per panicle $(0.0394)$, plant height $(0.0146)$ and test weight $(0.0076)$ had direct positive effect on seed 
yield per hill, indicating these are the main contributors to yield. However, days to $50 \%$ flowering $(0.0723)$, number of panicle per plant (0.4336) and flag leaf width (0.0759) had direct negative effect.

\section{Discussion}

The variability among genotypes indicates ample scope for selection for different quantitative characters for rice improvement. These findings are in accordance with the findings of Das et al. (2005), Singh et al. (2006), Dutt et al. (2007) who also observed significant variability for yield and its components in rice. The magnitude of phenotypic coefficient of variation was higher than genotypic coefficient of variation for all the characters which may be due to higher degree of interaction of genotypes with the environment. Similar findings were also reported by Chaubey and Singh (1994), Sharma and Richharia (1995) and Pandey et al. (2010). The proportion of genetic variability which is transmitted from parents to offspring is reflected by heritability (Lush 1949). High heritability alone is not enough to make sufficient improvement though selection in advance generation where accompanied by substantial amount of genetic advance. Similar results on heritability were also reported by Bhandarkar et al. (2002), Patil et al. (2003) and Vivek et al. (2004).

Johnson et al. (1955) suggested that heritability and genetic advance when calculated together would prove more useful in predicting the resultant effect of selection on phenotypic expression. Based on this consideration high heritability coupled with high genetic advance as percentage of mean was registered for seed yield per hill, harvest index, number of spikelets per panicle, biological yield and flag leaf length, suggesting preponderance of additive gene action in the expression of these characters. Therefore, selection may be effective through these characters. High heritability associated with moderate genetic advance as percent of mean was observed for test weight and panicle length. Whereas, days to $50 \%$ flowering recorded high heritability and low genetic advance as \% of mean which revealed the non- additive gene action in the expression of these characters in their inheritance, hence in this case selection may not be effective. These findings were in agreement with the findings of earlier researcher Singh et al. (2002), Mohammad et al. (2002) and Vaithiyalingan and Nadarajan (2006).

Genotypic correlation coefficients were of higher in magnitude than the corresponding phenotypic correlation coefficients which might be due to masking or modifying effect of environment (Singh 1980). These findings are corroborating the observations of Meenakshi et al. (1999), Chaubey and Singh (1994) and Bhattacharyya et al. (2007). Very close values of genotypic and phenotypic correlations were also observed between some character combinations, such as days to $50 \%$ flowering with flag leaf length and biological yield, harvest index with test weight and seed yield, plant height with number of spikelets per panicle and test weight, number of spikelets with biological yield, test weight with flag leaf length; which might be due to reduction in error (environmental) variance to minor proportions as reported by Dewey and Lu (1959). Thus selection for higher yield on the basis of above characters would be reliable. Similar findings were also reported by Rao et al. (1997), Prasad et al. (2001), Surek and Beser (2003) and Yogamenakshi et al. (2004).

A perusal of data revealed that biological yield showed negative significant direct correlation with grain yield $(0.378,0.367)$ at both genotypic and phenotypic levels. While, negative non-significant direct correlation was observed between grain yield with days to $50 \%$ flowering and plant height at both level but flag leaf width with only genotypic level. Similar negative correlation was also reported by Chaudhary and Das (1998) and Shanthi and Singh (2001). The genetic reasons for this type of negative association may be linkage or pleiotropy. According to NeWall and Eberhart (1961) when two characters show negative phenotypic and genotypic correlation it would be difficult to exercise simultaneous selection for these characters in the development of a variety. Hence, under such situations, judicious selection programme might be formulated for simultaneous improvement of such important developmental and component characters. 
When characters having direct bearing on yield are selected, their associations with other characters are to be considered simultaneously as this will indirectly affect yield. Significant positive correlations at both the levels were recorded for plant height with flag leaf length and panicle length; harvest index with number of tillers per hill, number of spikelets per plant, number of panicles per plant and flag leaf length with number of spikelets per panicle. However, number panicle per plant with flag leaf length, flag leaf width, biological yield; and harvest index with flag leaf length showed positive estimates but significant at genotypic level. Kole et al. (2008) also obtained the same association between plant height with panicle length and Ganesan et al. (1998) reported harvest index with panicles/plant, panicle length, grains/panicle and 100 grain weight.

The results of correlation coefficients implied that significant indirect negative correlations at both the levels were recorded for panicle length with number of tillers per hill, number of panicle per plant, flag leaf width, harvest index and biological yield with harvest index and test weight with number of spikelets per panicle. Some traits showed negative indirect effect to seed yield but significant at only genotypic level i.e. flag leaf width with harvest index, plant height and number of panicle per plant with days to $50 \%$ flowering, test weight. The overall results indicated that selection of higher panicle number, test weight with a reasonable balance for moderate spikelet number would particularly encourage the breeders to achieve higher grain yield. These results are in conformity with Nayak et al. (2001), Hasib and Kole (2004) and Khedikar et al. (2004).

Shrivastava and Sharma (1976) suggested that only direct yield components should be used for path analysis. Similar results of yield per plant with harvest index were reported by Ganesan et al. (1998) and Chaturvedi et al. (2008); with panicle length by Kishor et al. (2008); with test weight by Chaturvedi et al. (2008) and with harvest index, panicle length and 100 grain weight Chakraborty et al. (2010). The dimensions of residual effect were very low, which indicated the consideration of most of the yield contributing characters. Moreover, majority of values were less than unity, which indicated that inflation due to multicolinearity was minimal (Gravois and Helms 1992).

\section{Conclusion}

From the correlation and path study it may be concluded that the harvest index, number of tillers per hill, panicle length, number of spikelet per panicle and test weight are the most important characters that contributed directly to seed yield per hill. Thus a genotype with higher magnitude of these traits could be either selected from existing genotypes or evolved by breeding program for genetic improvement of yield in rice.

\section{Acknowledgements}

The authors are thankful to Directorate of Research, Allahabad Agricultural Institute-Deemed University, Allahabad (Uttar Pradesh) India, for providing the necessary facilities to undertake the present study and also thankful to M M Khetan, Indostat, Hyderabad for statistical analysis.

\section{References}

Al-Jibouri HA, Muller PA, Robinson HF. 1958. Genetic and environmental variances and co-variances in an upland cotton cross of inter specific origin. Agronomy J 50, 633-636. http://dx.doi:10.2134/agronj1958.00021962005000100020x

Bhandarkar S, Verma R, Kumar A. 2002. Genetic variability and correlation analysis in early duration rice. Plant Arch 2 (1), $95-98$.

Bhattacharyya R, Roy B, Kabi MC, Basu AK. 2007. Character association and path analysis of seed yield and Its attributes in rice as affected by bio-inoculums under tropical environment. Trop Agric Res Extn 10, 23-28.

Burton GW, De Vane EH. 1953. Estimating heritability in tall fescue (Festuca arundinacea) from replicated clonal material. Agronomy J 45, 478-481. http://dx.doi:10.2134/agronj1953.00021962004500100005x

Burton GW. 1952. Quantitative inheritance of grasses. Proc 6th Int, Grassland Congress, 1:277-283.

Chakraborty S, Das PK, Guha B, Sarmah KK, Barman B. 2010. Quantitative genetic analysis for yield and yield components in boro rice (Oryza sativa L.). Not Sci Biol 2(1), 117-120. 
Chaturvedi S, Lal P, Pandey MP, Verma S, Singh AP. 2008. Component analysis for grain yield in hybrid rice under 'tarai' condition. Oryza 45(1), 1-6.

Chaubey PK, Singh R. 1994. Genetic variability, correlation and path analysis of yield components of rice. Madras Agric J 81(9), 468470.

Chaudhary PKD, Das PK. 1998. Genetic variability, correlation and path analysis in deep water rice. Ann Agric Res 19(2), 120-124.

Das R, Borbora TK, Sarma MK. 2005. Genetic variability for grain yield in semi-deep water rice (Oryza sativa L.). Oryza 42(4), 313-314.

Dewey JR, Lu KH. 1959. A correlation and path co-efficient analysis of components of crested wheat seed production. Agronomy J 51 , 515-518. http://dx.doi:10.2134/agronj1959.00021962005100090002x

Dutt I, Mehla BS, Singh J. 2007. Multivariate analysis in rice (Oryza sativa L.). Nat J Plant Improvement 9(2), 115-118.

Falconer DS. 1981. Introduction to Quantitative Genetics. ELBS, Longman.

Fisher RA, Yates F. 1967. Statistical tables for Biological, Agricultural and Medical Research, Longmen Group Limited, London.

Ganesan K, Subramaniam M, Wilfred MW, Sundaram T. 1998. Correlation and path coefficient analysis of yield components in F2 and F3 generations of tall $x$ dwarf rice cross. Oryza 35(4), 329-332.

Gravois KA, Helms RS. 1992. Path analysis of rice yield and yield components as affected by seedling rate. Agronomy J 84, 1- 4. http://dx.doi:10.2134/agronj1992.00021962008400010001x

Hasib KM, Kole PC. 2004. Cause and effect relation-ship for yield and its components in scented rice hybrids involving gamma ray induced mutants. J Nuclear Agric Biol 33, 49-55.

Johnson HW, Robinson HF, Comstock RE. 1955. Estimates of genetic and environmental variability in soybeans. Agronomy J 47, 314318. http://dx.doi:10.2134/agronj1955.00021962004700070009x

Khedikar VP, Bharose AA, Sharma D, Khedikar YP, Khillare AS. 2004. Path coefficient analysis of yield components of scented rice. J Soil Crop 14, 198-210.

Kishor C, Prasad Y, Haider ZA, Kumar R, Kumar K. 2008. Quantitative analysis of upland rice. Oryza 45(4), 268-274.

Kole PC, Chakraborty NR, Bhat JS. 2008. Analysis of variability, correlation and path coefficients in induced mutants of aromatic nonbasmati rice. Trop Agric Res Extn 11, 60-64.

Lush JL. 1949. Heritability of quantitative characters in farm animals. Hereditas, suppl, 356-375.

Meenakshi T, Ratinam AAD, Backiyarani S. 1999. Correlation and path analysis of yield and some physiological characters in rainfed rice. Oryza 36(2), 154-156.

Mohammad T, Dera W, Ahmed Z. 2002. Genetic variability of different plant and yield characters in rice, Sarha J Agric 18(2), 207-210.

Nayak AR, Chaudhury D, Reddy JN. 2001. Correlation and path analysis in scented rice (Oryza sativa L.). Indian J Agric Res 35, 186-189.

NeWall LC, Eberhart SA. 1961. Clone and progeny evaluation in the improvement of switch grass (Panicum virgatum L.). Crop Sci 1, 117-121. http://dx.doi:10.2135/cropsci1961.0011183X000100020010x

Pandey P, Anurag PJ, Rangare NR. 2010. Genetic Parameters for Yield and Certain Yield Contributing Traits in Rice (Oryza sativa L.). Ann Plant Soil Res 12(1), 59-61.

Panse VG, Sukhatme PV. 1967. Statistical Methods of agricultural Workers. $2^{\text {nd }}$ edition, pp: 381, I.C.A.R Publ. New Delhi.

Patil PV, Sarawgi AK, Shrivastava MN. 2003. Genetic analysis of yield and quality traits in traditional aromatic accessions of rice. J Maharashtra Agric Univ 28(33), 255-258.

Prasad B, Patwary AK, Biswas PS. 2001. Genetic variability and selection criteria in fine rice (Oryza sativa L.). Pakistan J Biol Sci 4(10), 1188-1190. http://dx.doi:10.3923/pjbs.2001.1188.1190

Rao SA, Khan MA, Neilly TMC, Khan AA. 1997. Cause and effect relations of yield and yield components in rice (Oryza sativa L.). J Genet Bred 51(1), 1-5.

Shanthi P, Singh J. 2001. Genetic divergence for yield and its components in induced mutants of Mahsuri rice (Oryza sativa L.). Res Crop 2, 390-392.

Sharma MK, Richharia K. 1995. Genetic variability and diversity in rice under irrigated transplanted condition. J Agric Sci Soc North East India 8(2), 152-157.

Shrivastava MN, Sharma KK. 1976. Analysis of path coefficient in rice. Zeitsch Pflanzen 77, 174-177. 
Singh RP. 1980. Association of grain yield and its component in F1 and F2 population of rice. Oryza 17, 200-204.

Singh PK, Mishra MN, Hore DK, Pasnwar AS. 2002. Genetic variability in some indigenous lowland rice genotypes of North East India. Indian J Hill Farming 15(1), 113-115.

Singh SP, Singhar GS, Parray GA, Bhat GN. 2006. Genetic variability and character association studies in rice (Oryza sativa L.). Agri Sci Dig 26(3), 212-214.

Surek H, Beser N. 2003. Correlation and path coefficient analysis for some yield related traits in rice (Oryza sativa L.) under thrace conditions. Turk J Agri 27, 77-83.

Vaithiyalingan M, Nadarajan N. 2006. Correlation and path analysis in inter sub specific rice hybrids. Res Crop 6(2), 286-289.

Vivek, S, Surendra S, Singh SK, Singh H, Shukla V, Singh S. 2004. Analysis of variability and heritability in new plant type tropical Japonica rice (Oryza sativa L.). Environ Ecol 22(1), 43-45.

Yogamenakshi, Nadarajan N, Ambularmathi J. 2004. Correlation and path analysis on yield and drought tolerant attributes in rice (Oryza sativa L.) under drought stress. Oryza 41 (3\&4), 68-70. 